\title{
Assessment of basic physical parameters of current Canadian-American National Hockey League (NHL) ice hockey players
}

\author{
Martin Sigmund ${ }^{1, *}$, Steven Kohn ${ }^{2}$, and Dagmar Sigmundová ${ }^{1}$

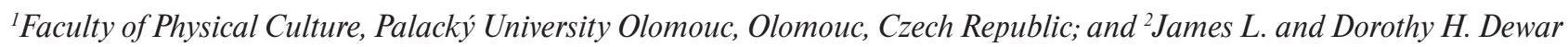 \\ College of Education and Human Services, Valdosta State University, Valdosta, GA, United States
}

Copyright: (C) 2016 M. Sigmund et al. This is an open access article licensed under the Creative Commons Attribution License (http://creativecommons.org/licenses/by/4.0/).

\begin{abstract}
Background: Physical parameters represent an important part of the structure of sports performance and significantly contribute to the overall performance of an ice hockey player. Basic physical parameters are also an essential part of a comprehensive player assessment both during the initial NHL draft and further stages of a professional career. For an objective assessment it is desirable to know the current condition of development of monitored somatic parameters with regard to the sports discipline, performance level and gaming position. Objective: The aim of this study was to analyze and present the level of development of basic physical characteristics [Body Height (BH) and Body Weight (BW)] in current ice hockey players in the Canadian-American NHL, also with respect to various gaming positions. Another aim is to compare the results with relevant data of elite ice hockey players around the world. Methods: The data of 751 ice hockey players (age range: 18-43 years; 100\% male) from NHL (2014/2015 season) are analyzed (goalkeepers, $n=67$; defenders, $n=237$; forwards, $n=447$ ). Statistical data processing was performed using a single factor ANOVA and Fisher's (LSD) post hoc test. The level of statistical significance was tested at a level of $p \leq .05$; $p \leq .01$. Effect size was expressed according to Cohen's $d$. Results: Current levels of monitored parameters of NHL players represent the values: $\mathrm{BH}=186.0 \pm 5.3 \mathrm{~cm}, \mathrm{BW}=91.7 \pm 6.9 \mathrm{~kg}$. Significant differences among positions were found for the BH (goalkeepers > defenders > forwards) and BW (defenders > goalkeepers $>$ forwards). Differences among forwards positions were also found for the $\mathrm{BH}$ (left wings $>$ right wings $>$ centers) and BW (left wings $>$ right wings > centers). Conclusion: The observed values represent the current level of basic physical parameters in professional ice hockey players in the NHL and can be considered reference values in this specific population group.
\end{abstract}

Keywords: body height, body weight, male, elite sport, NHL

\section{Introduction}

Current ice hockey can be defined as a multidimensional sport that requires a concordance of many determining factors to achieve success at the highest level (Burr et al., 2008). The achievement of the highest performance level requires significant development of motor abilities, skills and an overall high level of development of physical fitness. This is related to an assumption of optimum development of somatic parameters, which represent an important determinant of sports performance in ice hockey players at the highest performance level (Burr et al., 2008; Kutáč \& Sigmund,

\footnotetext{
* Address for correspondence: Martin Sigmund, Department of Recreology, Faculty of Physical Culture, Palacký University Olomouc, třída Míru 117, 77111 Olomouc, Czech Republic. E-mail: martin.sigmund@upol.cz
}

2015). The importance of morphological parameters is confirmed by involvement of somatic parameters in functional diagnostics of ice hockey players, along with exercise tests (Gledhill \& Jamnik, 2007; Hoff, Kemi, \& Helgerud, 2005; Quinney et al., 2008; Roczniok et al., 2013; Skowronek, Socha, Roczniok, \& Socha, 2013), just as in other sports (Malina, Bouchard, \& Bar-Or, 2004; McArdle, Katch, \& Katch, 2010; Tanner \& Gore, 2013). Athletes of various sports disciplines differ in somatic parameters because for each sports discipline specific morphological dispositions are appropriate. Similarly, the values of somatic parameters in athletes usually differ from the values of the common population. The differences in the values between athletes and the common population increase with increasing age of athletes and length of their training (Malina et al., 2004; Norton \& Olds, 2001). 
With regard to the level of development of basic somatic parameters in current senior ice hockey players, it has been demonstrated that a higher performance level is associated with a higher level of development of basic morphological parameters. The average values of body height and body weight in world class players of the highest performance levels ("A"), according to the ranking the International Ice Hockey Federation (IIHF), are $184.3 \pm 5.79 \mathrm{~cm}$ and $88.1 \pm 7.37 \mathrm{~kg}$. Another observation concerned a trend of the highest development of basic morphological parameters in relation to a higher performance level with respect to gaming positions (Sigmund, Riegerová, Sigmundová, \& Dostálová, 2014).

In the context of the above we formulated the following research question: "What is the specific level of development of basic somatic parameters in current professional ice hockey players in the Canadian-American NHL?"

The aim of this paper was to analyze and present the level of development of basic somatic characteristics in current ice hockey players in the Canadian-American NHL, also with respect to various gaming positions. Another aim was to compare the results with relevant data according to the ranking of the International Ice Hockey Federation (IIHF), with current data of the Czech top ice hockey league (ELH) and with the data of the Russian top ice hockey league, the Continental ice hockey league (KHL).

\section{Material and methods}

\section{Subjects}

The present study analyses available basic physical data of current players in the Canadian-American NHL; the nature of the survey is descriptive-comparative (Thomas, Nelson, \& Silverman, 2011). The observed values of the monitored morphological parameters in adult ice hockey players in the Canadian-American National Hockey League (NHL) were analyzed in October and November 2014. Personal data from a total of 751 players were processed (100\% male). The present data represent the values of current professional ice hockey players in the NHL. The average age of the monitored NHL players (2014/2015 season) was 27.01 years ( $S D=4.58$; range $18-43$ years). In addition, individual values of the monitored parameters were assigned to the subsets according to the respective gaming position: goalkeepers, $n=67$ (27.88 \pm 3.85 years); defenders, $n=237$ (27.08 \pm 4.81 years); and forwards, $n=447$ ( $26.83 \pm 4.55$ years). The analyzed data were based on relevant sources of all current teams active in the Canadian-American NHL $(N=30)$. The analytical survey included players of various nationalities, especially from Canada (50\%), USA (25\%), Sweden ( $8 \%$ ), Russia (4\%), Czech Republic (4\%), Finland (4\%), Slovakia (1\%) and others (4\%) (QuantHockey, 2015).

To convert the values to metric units we used the data from a conversion table (Malina et al., 2004). In our case we worked with the following conversions: 1 foot $=30.48 \mathrm{~cm} ; 1$ inch $=2.54 \mathrm{~cm}$; 1 pound $=0.454 \mathrm{~kg}$.

Comparison of data of NHL players $(N=751)$ with the data of the current elite ice hockey players, according to the IIHF ranking ( $N=808$; ranking "A", $n=384$, $\mathrm{BH}=184.3 \pm 5.8 \mathrm{~cm}, \mathrm{BW}=88.1 \pm 7.7 \mathrm{~kg}$; ranking "B", $n=217, \mathrm{BH}=183.2 \pm 5.3 \mathrm{~cm}, \mathrm{BW}=86.2 \pm 7.0 \mathrm{~kg}$; ranking “C”, $n=207, \mathrm{BH}=181.1 \pm 5.8 \mathrm{~cm}$, $\mathrm{BW}=80.7 \pm 8.6 \mathrm{~kg}$ ), respective players from the KHL $(N=51, \mathrm{BH}=184.5 \pm 5.6 \mathrm{~cm}, \mathrm{BW}=91.1 \pm 8.4 \mathrm{~kg})$ and $\operatorname{ELH}(N=413, \mathrm{BH}=184.2 \pm 5.5 \mathrm{~cm}$, $\mathrm{BW}=87.1 \pm 7.4 \mathrm{~kg}$ ), was carried out using its own published research (Kutáč \& Sigmund, 2015; Sigmund et al., 2014; Sigmund, Sigmundová, \& Kvintová, 2015).

\section{Statistical analysis}

Statistical results processing was performed using the Statistica (Version 10.0; StatSoft, Tulsa, OK, USA). Statistical quantities were calculated for all variables; distribution normality was verified. Parametric as well as non-parametric statistical tests were applied. The Shapiro-Wilk test was used to assess normality. For testing the significance of the differences a one factor analysis of variance (ANOVA) with subsequent applications of the Fisher's LSD post hoc test was used. The level of statistical significance was tested at $p \leq .05$ and $p \leq .01$. Effect size was expressed in $d$ values, where $d$ is Cohen's coefficient for effect size defined as a difference between two means divided by a standard deviation for the data. The most frequent assessment of effect size $d$ is 0.2 - small effect, 0.5 - moderate effect and 0.8 - large effect (Thomas et al., 2011).

\section{Results}

The results section presents the outcomes of an analytical survey and specifically defines the values of the monitored morphological parameters of current NHL players. Tables 1 and 2 show the average values of the monitored morphological parameters of the entire sample $(N=751)$ of current NHL players, also with respect to their gaming positions.

The mean values of body height, body weight and BMI of current ice hockey players of the CanadianAmerican NHL are $186.0 \pm 5.3 \mathrm{~cm}$ and $91.7 \pm 6.9 \mathrm{~kg}$. In terms of gaming positions we revealed the highest 
Table 1

Body height and body weight and statistical comparison of differences and effect size of current ice hockey players of $N H L$ - goalkeepers $(G)$, defenders $(D)$, forwards $(F)$

\begin{tabular}{lrrrrrrrrr}
\hline & $n$ & $M$ & $S D$ & Minimum & Maximum & Comp. & $\Delta$ & $p$ & $d$ \\
\hline Body height (cm) & & & & & & & & & \\
$\quad$ All players & 751 & 186.0 & 5.3 & 165.1 & 205.7 & & & & \\
Goalkeepers & 67 & 188.3 & 4.4 & 177.8 & 200.7 & G - D & 0.9 & .198 & 0.18 \\
Defenders & 237 & 187.4 & 5.2 & 175.3 & 205.7 & G - F & 3.4 & .001 & 0.66 \\
Forwards & 447 & 184.9 & 5.2 & 165.1 & 203.2 & D - F & 2.5 & .001 & 0.48 \\
Body weight (kg) & & & & & & & & & \\
All players & 751 & 91.7 & 6.9 & 68.1 & 118.0 & & & & \\
Goalkeepers & 67 & 90.7 & 6.7 & 75.0 & 106.7 & G - D & 2.3 & .012 & 0.36 \\
Defenders & 237 & 93.0 & 6.5 & 76.8 & 115.3 & G - F & 0.2 & .827 & 0.02 \\
Forwards & 447 & 90.5 & 7.0 & 67.8 & 118.0 & D - F & 2.5 & .001 & 0.36 \\
\hline
\end{tabular}

Note. Comp. $=$ comparison; $\Delta=$ difference of means.

Table 2

Body height and body weight and statistical comparison of differences and effect size of current ice hockey forwards of NHL

\begin{tabular}{lccccccccc}
\hline & $n$ & $M$ & $S D$ & Minimum & Maximum & Comp. & $\Delta$ & $p$ & $d$ \\
\hline Body height (cm) & & & & & & & & & \\
$\quad$ Forwards & 447 & 184.9 & 5.2 & 165.1 & 203.2 & & & \\
$\quad$ Centers & 196 & 184.6 & 5.2 & 167.6 & 200.7 & $\mathrm{C}-\mathrm{R}$ & 0.4 & .509 & 0.07 \\
$\quad$ Right wings & 119 & 185.0 & 5.4 & 170.2 & 198.1 & $\mathrm{C}-\mathrm{L}$ & 0.8 & .168 & 0.15 \\
$\quad$ Left wings & 132 & 185.4 & 5.0 & 165.1 & 203.2 & $\mathrm{R}-\mathrm{L}$ & 0.4 & .539 & 0.08 \\
Body weight (kg) & & & & & & & & & \\
$\quad$ Forwards & 447 & 90.5 & 7.0 & 67.8 & 118.0 & & & \\
$\quad$ Centers & 196 & 89.2 & 6.5 & 69.1 & 110.3 & $\mathrm{C}-\mathrm{R}$ & 2.2 & .009 & 0.32 \\
$\quad$ Right wings & 119 & 91.4 & 7.0 & 75.5 & 118.0 & $\mathrm{C}-\mathrm{L}$ & 2.4 & .007 & 0.36 \\
$\quad$ Left wings & 132 & 91.6 & 7.0 & 67.8 & 118.0 & $\mathrm{R}-\mathrm{L}$ & 0.2 & .819 & 0.03 \\
\hline
\end{tabular}

Note. Comp. $=$ comparison; $\Delta=$ difference of means; $\mathrm{C}=$ Centers; $\mathrm{R}=$ Right wings; $\mathrm{L}=$ Left wings.

value of body height in ice hockey goalkeepers, followed by defenders and forwards. The differences in body height values with respect to gaming positions range between 0.9 and $3.4 \mathrm{~cm}$. A comparison of body height of goalkeepers and forwards showed a difference of $3.4 \mathrm{~cm}$, which can be considered significant $(p<.001$; $d=0.66)$. The difference interval in body weight values with respect to gaming positions is $0.2-2.5 \mathrm{~kg}$. The highest values of body weight were observed in ice hockey defenders. Body weight of goalkeepers and forwards is almost identical. The difference in body weight between defenders and forwards is $2.5 \mathrm{~kg}$ and between defenders and goalkeepers is $2.3 \mathrm{~kg}$, which can be considered statistically significant, but with a lower value of the effect size $(p<.001 ; d=0.36$ respectively $p=.012 ; d=0.36$ ) (Table 1 ).

Regarding the fact that the gaming position of an ice hockey forward is represented by three levels, their physical parameters are analyzed for the positions of center forward, right wing and left wing. Overall, it should be stated that in a majority of compared pairs, no statistically significant differences were observed. Also, the value of the effect size is relatively low and insignificant in all comparisons. The highest values of body height were observed in left wing forwards, we also observed a trend of higher values of body weight in right and left wing forwards in comparison with lower values of center forwards (Table 2).

The data of the current NHL players are presented in relation to the game position and are compared with the values of the somatic parameter of players operating in the Russion KHL and Czech ELH, and with data of players from all over the world according to the ranking of the IIHF.

Figures 1 and 2 are a graphical comparison of values of body height and body weight and the values of 


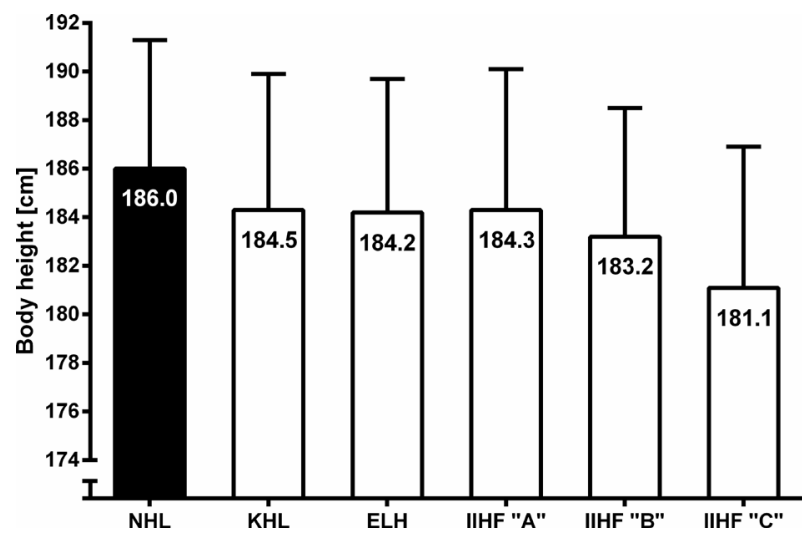

Figure 1. Values of body height of current players of ice hockey Canadian-American NHL, players of the Russian KHL, players of the Czech ELH and players in the world ranking by performance level IIHF.

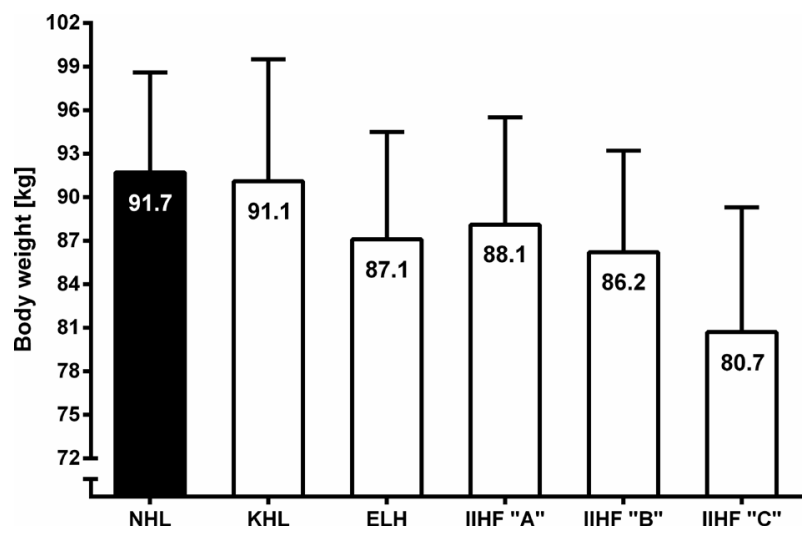

Figure 2. Values of body weight of current players of ice hockey Canadian-American NHL, players of the Russian KHL, players of the Czech ELH and players in the world ranking by performance level IIHF.

current NHL players above. The figures show that the highest values of body height and body weight achieved NHL players.

The effect size of the difference in body height of NHL players compared with players from KHL, ELH and IIHF "A" is low $(d=0.28,0.34,0.32)$. Compared with the players IIHF " $B$ " already represents a difference of level $3 \mathrm{~cm}$, which badly considered as moderately significant difference $(d=0.53)$. The highest difference was found in relation to the IIHF " $\mathrm{C}$ " at the level of $5 \mathrm{~cm}$, which can be considered high effect size significance $(d=0.91)$.

The effect size of the difference in body weight of NHL players compared with players from Russian $\mathrm{KHL}$ at a level lower than $1 \mathrm{~kg}$ is considered to be insignificant difference $(d=0.08)$. The lower body weight of $4.6 \mathrm{~kg}$ for players from Czech ELH compared with NHL players can be considered as moderately difference $(d=0.65)$. Similarly a comparison with players
IIHF "A" $(d=0.50)$. Lower body weight IIHF "B" $(5.5 \mathrm{~kg})$ is the strong effect size difference $(d=0.80)$. The biggest difference in body weight at $11 \mathrm{~kg}$ was found in the players of IIHF "C" $(d=1.50)$.

\section{Discussion}

The monitored parameters represent important factors influencing possible entry of a player into the Canadian-American NHL, at the same time they inform of the current level of development of the main morphological parameters in the monitored population group. The overall development of physical parameters is influenced by a combination of a secular trend and sport selection, which is determined by the requirements and the level of a specific league (Sigmund, Riegerová, \& Dostálová, 2012).

In our case, the players are in apparently the best ice hockey league in the world and therefore it is desirable to know the exact parameters of the current players, especially with respect to their gaming positions (Quinney et al., 2008; Stanula, Roczniok, Maszczyk, Pietraszewski, \& Zajac, 2014; Vescovi, Murray, \& VanHeest, 2006). Basic morphological parameters, together with the knowledge of body composition, development of strength in the upper and lower body parts, and optimum development of aerobic $\left(\mathrm{VO}_{2} \max \right.$ scores $\pm 56-60 \mathrm{ml} / \mathrm{kg} / \mathrm{min})$ and anaerobic capacity (AnC) (total AnC of elite ice hockey players is $\pm 1100-1200 \mathrm{~W}$; relative $\mathrm{AnC} / \mathrm{kg}$ of elite ice hockey players is $\pm 13 \mathrm{~W} / \mathrm{kg}$ ) are considered the main prediction factors of possible success and performance, especially in young players entering the Canadian-American NHL (Garrett \& Kirkendall, 2000; Montgomery, 2006; Peyer, Pivarnik, Eisenmann, \& Vorkapich, 2011; Potteiger, Smith, Maier, \& Foster, 2010; Tarter et al., 2009). If the overall index of the above mentioned prediction factors is around the $90^{\text {th }}$ percentile, there is a $60-72 \%$ probability that a young ice hockey defender or forward will join an NHL team during the following four years (Tarter et al., 2009).

Systematic monitoring of basic body parameters in ice hockey players was performed already in the second decade of the $20^{\text {th }}$ century in North America. Specifically, from 1917 Montreal players were regularly tested for basic morphological and functional parameters in at that time beginning Canadian-American national ice hockey league (NHL) (Montgomery, 2006). The dynamic development of ice hockey and the increasing demands on the development of morphological parameters is also documented by the positive development of body height and body weight in NHL players. Since 1920 s to 1930 s to the present, the average body height 
in NHL players increased by more than $10 \mathrm{~cm}$. A significant aspect is an increase in body weight by $17 \mathrm{~kg}$ in current NHL players in comparison with players from the early $20^{\text {th }}$ century (Montgomery, 2006). On the contrary, a period of significant positive acceleration of body height and body weight in top ice hockey players in the Czech Republic is especially 1970s and 1980s. A significant increase in body height and body weight in Czech top ice hockey players also occurred during the first decade of the $21^{\text {st }}$ century, particularly with respect to gaming positions (Sigmund et al., 2012).

Currently, there are some changes regarding the gaming positions. A general principle was that the tallest and heaviest were ice hockey defenders, followed by forwards and finally goalkeepers. In recent years however, the highest values of body height have been observed in ice hockey goalkeepers, particularly in North American ice hockey leagues. The preference of ice hockey goalkeepers with the above-average values of body height is obvious both at an international level and in the Canadian-American NHL (Palmer \& Spriet, 2008; Sigmund et al., 2014). The observed increases in the monitored physical parameters in ice hockey players in NHL are affected by a mutual combination of a secular trend, sport selection and the generally increasing demands on the morphological and functional dispositions of current players (Sigmund et al., 2012). Another factor is the influence of the so-called "global sport selection", where a significant proportion of NHL players comprise the best players particularly from Sweden, Russia, Czech Republic, Finland and Slovakia. These players, apart from a significant level of development of ice hockey skills, also have the required morphological and functional dispositions that allow these players to succeed in the CanadianAmerican ice hockey league. A significant increase in the number of foreign players from other than North American countries occurred at the turn of 1970s and 1980s. The proportion of these players is currently $25 \%$ of all NHL players, another $25 \%$ are players from the United States of America and the highest percentage traditionally consists of Canadian players (50\%) (QuantHockey, 2015).

The average value of body height of current ice hockey players of the Canadian-American NHL $(N=751)$ is $186.0 \pm 5.3 \mathrm{~cm}$. The observed value of body height represents a difference of nearly $2 \mathrm{~cm}$ in favor of NHL players in comparison with the average values of current world ice hockey players of top performance levels according to the ranking of the IIHF, which is $184.3 \pm 5.8 \mathrm{~cm}$ (Sigmund et al., 2014). The values of body height of current world players of top performance levels are almost identical with the average values of Czech players in the top Czech league, the ELH. The current average body height values of Czech players in the ELH represent $184.2 \pm 5.5 \mathrm{~cm}$ and are almost identical with the values of players in the top Russian national league (KHL) (Kutáč \& Sigmund, 2015; Sigmund et al., 2015) (Figure 1).

The average values of body weight of current ice hockey players of the Canadian-American NHL $(N=751)$ is $91.7 \pm 6.9 \mathrm{~cm}$ (Figure 2). The observed value of body weight represents a difference of nearly $4 \mathrm{~kg}$ in favor of NHL players in comparison with the average values of current world ice hockey players of top performance levels according to the ranking of the International Ice Hockey Federation (IIHF) (Sigmund et al., 2014). A comparison of the level of development of body weight of the current Czech players in the top league in the Czech Republic (ELH) shows significantly lower values, on average by $4-5 \mathrm{~kg}$, compared with NHL players (Sigmund et al., 2012). Similar values of development of body weight as in NHL players are achieved by players of the top Russian league, the KHL. Also here we observed average values exceeding the 91 kg limit (Kutáč \& Sigmund, 2015; Sigmund \& Dostálová, 2011). Taking into account that top level players have approximately the same value of body fat proportion $(10-12 \%)$, the difference in body weight is attributed to a higher development of fat free mass, represented primarily by the development of lean muscle mass. This fact might be considered a significant factor affecting the high performance of NHL players, and a factor that determines the entry to and success in the NHL.

An analysis of the values of development of body height in NHL players indicates that the highest values of body height are achieved by goalkeepers. Only then come defenders and forwards. Increasing values of body height of ice hockey goalkeepers have been observed in recent years particularly in North American junior leagues, which increasingly prefer ice hockey goalkeepers with above-average body height values (Palmer \& Spriet, 2008). Also in the senior category at an international level and particularly in the NHL there are now more ice hockey goalkeepers with body height ranging from 190 to $200 \mathrm{~cm}$ (Kutáč \& Sigmund, 2015).

As far as body weight of NHL players is concerned, the highest values are observed in ice hockey defenders, lower and almost identical values are observed in goalkeepers and forwards. The highest body height values of ice hockey defenders are also reported by other studies (Burr et al., 2008; Montgomery, 2006; Quinney et al., 2008). In overall terms, in prestigious world leagues such as the NHL and the Russian KHL the requirements for basic morphological parameters are significantly higher. This especially applies to body weight values of ice hockey defenders in the 
Canadian-American NHL and KHL, which achieved 93 kg (Burr et al., 2008; Kutáč \& Sigmund, 2015; Montgomery, 2006; Quinney et al., 2008; Sigmund \& Dostálová, 2011).

Current top ice hockey players in the position of defenders achieve body height of over $186 \mathrm{~cm}$ and body weight of over $93 \mathrm{~kg}$. These morphological dispositions allow defense activities at a high level, because the use of body dispositions represents an important precondition for game activities of top ice hockey defenders. Particularly defense activities in an own playing zone, in the corners and goal areas require an exceptional development of basic morphological parameters with an emphasis on body weight and its development in the form of the fat-free mass. NHL ice hockey defenders are divided into four game types such as Offensive D-Man, Defensive D-Man, Two-Way D-Man and Enforcer D-Man. The use of a high development of basic morphological characteristics in the activity of an ice hockey defender is typical especially for the defensive and enforcer types. These defenders take advantage of their physical qualities in their active approach to the opponents with highly developed strength abilities, highly aggressive playing and overall durability (Kutáč \& Sigmund, 2015).

Regarding the gaming position and possible relationships during sports performance, NHL ice hockey forwards are divided into six different types. In a practical environment they are defined as Playmaker, Sniper, Two-Way Forward, Power Forward, Grinder and Enforcer. The highest requirements for the development of body height and body weight are placed on Power Forward, Grinder and Enforcer. Common features of these types of forwards represent the use of body size in a game, development of strength abilities and general gaming aggressiveness (Kutáč \& Sigmund, 2015). In NHL ice hockey forwards the highest values of the development of the monitored features were observed in wings, lower values in centers. This is related to the tactics and organization of the game, during which players on the wings take more personal and board checks than players in the open field. This fact assumes a higher level of development of body weight and the proportion of fat free mass.

The above mentioned gaming positions and selected player types show the importance of an optimum development of somatic parameters as an important predictor for achieving high performance. Different values of development of morphological parameters with respect to gaming positions were also confirmed in female ice hockey players (Geithner, Lee, \& Bracko, 2006; Ransdell \& Murray, 2011).

Not every physical characteristic could be expected to play a role in this selection process, but two that are important and for which substantial data assemblies exist, are height and weight. Physical anthropometric data are valuable in helping predict ice hockey playing potential (Burr et al., 2008).

As the limits of this study, we consider working with the secondary data. Basic somatic characteristics were evaluated by the club medical doctors. Despite this fact, however, data, such as body weight and body height are among the reliable measurements in medical practice (Sebo, Beer-Borst, Haller, \& Bovier, 2008).

\section{Conclusions}

The present outcomes might represent reference values of the monitored physical characteristics of current professional NHL players. These values indicate the current level of optimum development of basic physical parameters that predict possible success in the league, taking into account various gaming positions. The present data might be practically used in the field of sports anthropology and working with young players in order to detect sports talent and to further develop such talent. The findings support the assumption of the importance of physical parameters as a significant factor of sports performance.

\section{Conflict of interest}

There were no conflicts of interest.

\section{References}

Burr, J. F., Jamnik, R. K., Baker, J., Macpherson, A., Gledhill, N., \& McGuire, E. J. (2008). Relationship of physical fitness test results and hockey playing potential in elitelevel ice hockey players. Journal of Strength and Conditioning Research, 22, 1535-1543.

Garrett, W. E., \& Kirkendall, D. T. (2000). Exercise and sport science. Philadelphia, PA: Lippincott Williams \& Wilkins.

Geithner, C. A., Lee, A. M., \& Bracko, M. R. (2006). Physical and performance differences among forwards, defensemen, and goalies in elite women's ice hockey. Journal of Strength and Conditioning Research, 20, 500-505.

Gledhill, N., \& Jamnik, V. (2007). Detailed assessment protocols for NHL entry draft players. Toronto: York University.

Hoff, J., Kemi, O. J., \& Helgerud, J. (2005). Strength and endurance differences between elite and junior elite ice hockey players. The importance of allometric scaling. International Journal of Sports Medicine, 26, 537-541.

Kutáč, P., \& Sigmund, M. (2015). A comparison of somatic variables of elite ice hockey players from the Czech ELH and Russian KHL. Journal of Human Kinetics, 45, 187-195. 
Malina, R. M., Bouchard, C., \& Bar-Or, O. (2004). Growth, maturation, and physical activity (2nd ed.). Champaign, IL: Human Kinetics.

McArdle, W. D., Katch, F. I., \& Katch, V. L. (2010). Exercise physiology: Nutrition, energy, and human performance (7th ed.). Baltimore, MD: Lippincott Williams \& Wilkins.

Montgomery, D. L. (2006). Physiological profile of professional hockey players - a longitudinal study. Applied Physiology, Nutrition and Metabolism, 31, 181-185.

Norton, K., \& Olds, T. (2001). Morphological evolution of athletes over the 20th century. Sports Medicine, 31, 763-783.

Palmer, M. S., \& Spriet, L. L. (2008). Sweat rate, salt loss, and fluid intake during an intense on-ice practice in elite Canadian male junior hockey players. Applied Physiology, Nutrition, and Metabolism, 33, 263-271.

Peyer, K. L., Pivarnik, J. M., Eisenmann, J. C., \& Vorkapich, M. (2011). Physiological characteristics of national collegiate athletic association division I ice hockey players and their relation to game performance. Journal of Strength and Conditioning Research, 25, 1183-1192.

Potteiger, J. A., Smith, D. L., Maier, M. L., \& Foster, T. S. (2010). Relationship between body composition, leg strength, anaerobic power, and on-ice skating performance in division I men's hockey athletes. Journal of Strength and Conditioning Research, 24, 1755-1762.

QuantHockey. (2015). NHL nationality breakdown from 1917-18 to 2015-16. Retrieved from http://www.quanthockey.com/TS/TS_PlayerNationalities.php

Quinney, H. A., Dewart, R., Game, A., Snydmiller, G., Warburton, D., \& Bell, G. (2008). A 26 year physiological description of a National Hockey League team. Applied Physiology, Nutrition and Metabolism, 33, 753-760.

Ransdell, L. B., \& Murray, T. (2011). A physical profile of elite female ice hockey players from the USA. Journal of Strength and Conditioning Research, 25, 2358-2363.

Roczniok, R., Maszczyk, A., Stanula, A., Czuba, M., Pietraszewski, P., Kantyka, J., \& Starzyński, M. (2013). Physiological and physical profiles and on-ice performance approach to predict talent in male youth ice hockey players during draft to hockey team. Isokinetics and Exercise Science, 21, 121-127.

Sebo, P., Beer-Borst, S., Haller, D. M., \& Bovier, P. A. (2008). Reliability of doctors' anthropometric measurements to detect obesity. Preventive Medicine, 47, 389-393.

Sigmund, M., \& Dostálová, I. (2011). Základní morfologické charakteristiky, tělesné složení a segmentální analýza u vybraných vrcholových hráčů ledního hokeje nejvyšší ruské soutěže [The basic morphological characteristics, body composition and segmental analysis in elite-level ice hockey players of the professional Russian hockey league]. Česká antropologie, 61(2), 25-31.

Sigmund, M., Riegerová, J., \& Dostálová, I. (2012). Vývoj základních morfologických parametrů u vrcholových seniorských hráčů ledního hokeje v České republice v kontextu let 1928-2010 [Development of the basic morphological characteristics in the elite-level senior ice hockey players in the Czech Republic in the context of years 1928-2010]. Česká antropologie, 62(2), 29-35.

Sigmund, M., Riegerová, J., Sigmundová, D., \& Dostálová, I. (2014). Analýza základních morfologických charakteristik současných světových seniorských hráčů ledního hokeje ve vztahu k výkonnostní úrovni podle rankingu Mezinárodní hokejové federace [Analysis of the basic morphological characteristics of current ice hockey players from around the world in relation to level of performance according to ranking of International Ice Hockey Federation]. Česká antropologie, 64(2), 34-39.

Sigmund, M., Sigmundová, D., \& Kvintová, J. (2015). Basic physical profile of current Czech elite male ice hockey players - references values. Life Science Journal, 12(2), 9-13.

Skowronek, T., Socha, T., Roczniok, R., \& Socha, S. (2013). The predictive value of various anaerobic capacity indices in relation to specific on-ice performance tests in ice hockey players. Life Science Journal, 10(4), 2228-2832.

Stanula, A., Roczniok, R., Maszczyk, A., Pietraszewski, P., \& Zając, A. (2014). The role of aerobic capacity in highintensity intermittent efforts in ice-hockey. Biology of Sport, 31, 193-199.

Tanner, R., \& Gore, C. (2013). Physiological tests for elite athletes (2nd ed.). Champaign, IL: Human Kinetics.

Tarter, B. C., Kirisci, L., Tarter, R. E., Weatherbee, S., Jamnik, V., McGuire, E. J., \& Gledhill, N. (2009). Use of aggregate fitness indicators to predict transition into the National Hockey League. Journal of Strength and Conditioning Research, 23, 1828-1832.

Thomas, J. R., Nelson, J. K., \& Silverman, S. J. (2011). Research methods in physical activity (6th ed.). Champaign, IL: Human Kinetics.

Vescovi, J. D., Murray, T. M., \& VanHeest, J. L. (2006). Positional performance profiling of elite ice hockey players. International Journal of Sports Physiology and Performance, 1, 84-94. 